Georgetown University Law Center

Scholarship @ GEORGETOWN LAW

2016

\title{
Evaluating Joint Ventures: Economic Analysis Checklist
}

Steven C. Salop

Georgetown University Law Center, salop@law.georgetown.edu

This paper can be downloaded free of charge from:

https://scholarship.law.georgetown.edu/facpub/1663

http://ssrn.com/abstract=2756554

This open-access article is brought to you by the Georgetown Law Library. Posted with permission of the author. Follow this and additional works at: https://scholarship.law.georgetown.edu/facpub

Part of the Antitrust and Trade Regulation Commons, and the Commercial Law Commons 


\title{
Evaluating Joint Ventures: \\ Economic Analysis Checklist
}

\author{
Steven C. Salop*
}

BMI,${ }^{1}$ Engineers, ${ }^{2}$ NCAA, ${ }^{3}$ Cal Dental, ${ }^{4}$ Dagher, ${ }^{5}$ American Needle ${ }^{6}$, Visa, ${ }^{7}$ Northwest Stationers, ${ }^{8}$ and Cascades, ${ }^{9}$ all involve the formation of joint ventures ("JVs") among actual or potential competitors, and the specific restraints and conduct of the JVs. ${ }^{10}$ Some of these joint ventures replace or supplement independent competition among JV members by JV control over sales or purchases. Others involve restraints on the competitive behavior of JV members. Others involve the JV providing a technology input or other inputs to the JV members who then compete independently in the market, though their competitive behavior may be constrained. This short article focuses on the economic issues that are relevant to evaluating the competitive effects on prices, output and consumer welfare resulting from the various types of restraints instituted by JVs when they are formed and by subsequent JV operations or restraints. The article provides a Checklist of 20 questions to frame evaluation of likely potential competitive

* Professor of Economics and Law, Georgetown University Law Center, and Senior Consultant, Charles River Associates. Professor Salop served as a consultant to the staff on the Competitor Collaboration Guidelines. I would like to thank Jonathan Baker, Andrew Gavil, Michael McFalls and John Woodbury for helpful comments.

1 Broadcast Music, Inc. v. CBS, 441 U.S. 1 (1979).

2 National Soc'y of Professional Engineers v. United States, 435 U.S. 679, (1978)

3 NCAA v. Bd. of Regents of Univ. of Okla., 468 U.S. 85 (1984).

4 Cal. Dental Ass'n v. FTC, 526 U.S. 756 (1999)

5 Texaco Inc. v. Dagher, 547 U.S. 1 (2006)

6 American Needle, Inc. v. National Football League, 560 U.S. 183 (2010)

7 United States v. Visa, 344 .3d 229 (2d Cir. 2003)

8 Northwest Wholesale Stationers v. Pac. Stationery, 472 U.S. 284 (1985)

9 Cascades Computer Innovation LLC v. RPX Corporation et al., No. 4:12-cv-01143 (N.D. Cal. Dec. 3, 21013)

10 These cases collectively raise important doctrinal issues regarding the appropriate presumptions and legal standards, including burdens of production. Decision theory can usefully be applied to these issues. For example, see C. Frederick Beckner III \& Steven C. Salop, Decision Theory and Antitrust Rules, 67 ANTITRUST L.J. 41 (1999). 
harms and cognizable competitive benefits. These economic questions can be used to flesh out the economic framework of the Competitor Collaboration Guidelines. ${ }^{11}$

The Checklist is organized as follows. Section A focuses on potential competitive harms. Section B then turns to potential competitive benefits. Section $C$ focuses on the determination of net competitive effects. This sequencing roughly corresponds to the burden-shifting formulation of the rule of reason. However, it is important to note that this sequencing should not be approached rigidly. A finding of a lack of efficiency benefits might suggest that the motivation of the JV is to achieve and exercise market power to the detriment of consumers, thereby supporting an inference of harm. ${ }^{12}$ Moreover, under a quick look to condemn standard, efficiency benefits are examined first, albeit with a possibly lower burden of proof on the JV. If that proof fails, answering some of these harm questions may turn out to be unnecessary as a matter of law under this quick look standard. ${ }^{13}$

\section{A. Potential Competitive Harms}

A JV and its specific restraints can lead to harms to consumers and the competitive process. These harms can arise through collusive or exclusionary effects. The following questions focus on potential competitive harms under the interim assumption that the restraints do not have any competitive benefits. Procompetitive efficiency benefits are discussed in the following section.

1. Would the JV member firms likely be significant actual or potential competitors, absent the $J V$ ? Even if the firms are not currently actual competitors (e.g., if they are producing vertically related or otherwise complementary products), they might be potential entrants (or entrant sponsors or facilitators) into each other's markets. ${ }^{14}$ A JV among firms in vertically connected markets (or a JV among complementary product producers) can raise foreclosure concerns. The remainder of this Checklist generally supposes that the members are actual or potential competitors to one another and/or the JV. The foreclosure concerns discussed

11 U.S. Dep'T OF Justice \& Fed. Trade COMM'N, Antitrust Guidelines FOR COLLABORATIONS AMONG COMPETITORS (2000)

12 Decision theory suggests that a sequential decision process be structured to focus first on the evidence that is least-cost as well as evidence most likely to affect the decision by undoing the presumption. For further analysis, see Beckner \& Salop, supra note 10. Steven C. Salop, The Evolution and Vitality of Merger Presumptions: A Decision-Theoretic Approach, 80 ANTITRUST L.J. 269 (2015). Evidence indicating lack of procompetitive purpose suggests that the purpose and effect of a firm or JV's conduct is to create market power that can lead to competitive harms. Thus, evidence that the JV lacks cognizable efficiency benefits in principle could strengthen an inference of harm. This is also a decision theory rationale for focusing first on efficiency benefits in the quick look to condemn standard.

${ }^{13}$ For example, see NCAA, supra note 3.

${ }^{14}$ For example, see Steven C. Salop and Daniel P. Culley, Revising the U.S. Vertical Merger Guidelines:Policy Issues and an Interim Guide for Practitioners, J. ANTITRUST ENFORCMENT 1 (2015) 
below also apply to JVs involving vertically related or complementary product producers, for example, a JV comprised of a pool of complementary patents.

2. After the formation of the JV, do the JV members continue to have the ability to compete independently as JV members, or are they constrained solely to operate in the market through the JV? If the members are permitted to compete independently, then there is less likely to be consumer harm. However, the JV rules might constrain this competition in various ways ranging from contractual prohibitions on competition or fees that must be paid to the JV to unilateral incentives to forego competition.

3. Assuming there are no JV restraints on this independent competition, do the JV members have economic incentives to compete independently? Do any JV practices facilitate pricing coordination among its members? Even if the JV members are not formally restrained by the $\mathrm{JV}$, they may lack incentives to compete because they would not want to disrupt the profit potential of the JV. For example, if the only two firms in a market formed a JV produced a product similar to that of the JV, the individual firms each unilaterally might choose to forgo independent competition that would lead to lower prices. Incentives to compete would depend on the number of JV members, their respective ownership interests in the JV (both financial interest and control/influence over JV decision-making), as well as their market shares and the shares of non-member competitors, market concentration and entry barriers. ${ }^{15}$ The JV also might facilitate collusion or coordination among its members, for example, by providing a forum for communications or through formal information exchange arrangements.

4. Are the JV members required to purchase inputs or technology from the JV, or do they have an ability to continue to compete independently "outside" of the JV by acquiring alternative inputs and technology without compensating the JV? If the members have the ability and incentive to compete independently outside the JV, then the ability of the JV to charge supracompetitive input prices to members or supracompetitive output prices to downstream customers may be constrained. If the individual members compete independently of the JV with non-JV technology and inputs, then the members may provide a competitive constraint to one another and the JV. For example, the Court in BMI suggested that since CBS could have transacted with individual composers for music performance rights, then BMI and ASCAP may have lacked the power to charge supracompetitive prices. ${ }^{16}$

\footnotetext{
15 See generally Daniel P. O'Brien and Steven C. Salop, Competitive Effects of Partial Membership: Financial Interest and Corporate Control, 67 ANTITRUST L.J. 559 (2000).

16 BMI, supra note 1. A separate issue is whether or not CBS had a practical ability to transact outside the JV and constrain the prices of the blanket licenses, in light of the higher fees for per program licenses and the fact that certain owned programming such as movies had music already embedded in it.
} 
5. Are there other non-JV competitors, either individual firms who are not members of the JV or other JVs? If so, then the JV similarly may be less likely to have the power to harm competition.

6. If one were to consider a hypothetical merger of the JV and its members as a single firm, would that hypothetical monopolist have market power to maintain higher prices, relative to there being no JV? This scenario can be a useful way to frame the competitive effects analysis, as well as market definition. In carrying out this analysis, however, it is necessary to avoid the Cellophane Fallacy by recognizing that the potential harm from the JV (or its conduct) may be to maintain monopoly power and avoid competition or entry that otherwise would cause prices to fall (i.e., as opposed to the JV restraints causing prices to rise above the current level). ${ }^{17}$ This is an important practical issue because elimination of the JV or its restraints may increase competition among JV members, which could lead in turn to downstream prices falling below the current prices charged by the JV. ${ }^{18}$

7. What is the impact on effective market concentration caused by the JV formation, taking into account the members' ownership interests (both financial interest and control/influence) in the JV, the market share of the JV, constraints on independent competition by the JV members, and any competition from non-members? A "modified" HHI can be calculated that takes these membership interests and other factors into account. ${ }^{19}$ Of course, reasonably projecting the JV market share may be difficult if the evaluation takes place at the time the $\mathrm{JV}$ is just being formed.

8. What is the impact of the JV formation on upward pricing pressure, taking into account any constraints on independent competition by JV members, and competition from non-members? A "modified" GUPPI similarly can be calculated that takes these membership interests and other factors into account. ${ }^{20}$

9. Are there barriers to entry or expansion that would prevent effective competition from nonmembers of the JV, either individually or as members of rival JVs? If there are prohibitive barriers and they also constrain JV members competing outside the JV, for example, then the

${ }^{17}$ For further details, see Steven C. Salop, The First Principles Approach to Antitrust, Kodak, and Antitrust at the Millennium, 68 ANTITRUST L.J. 187-202 (2000). See also Dennis W. Carlton and Steven C. Salop, You Keep On Knocking But You Can't Come In: Evaluating Restrictions On Access To Input Joint Ventures, 9 HARVARD J. LAW \& TECH 319 (1996).

18 For example, suppose that the NCAA had set the price of broadcast rights at the point where further price increases would have been unprofitable because they would have caused substantial substitution to other programming. While this would be a constraint on further price increases, it would not be relevant to determining whether a prohibition on joint negotiation of those rights would have caused the prices to fall.

19 O'Brien and Salop, supra note 15.

${ }^{20} I d$. 
JV might be considered an essential facility. ${ }^{21}$ At the other extreme, if there are no such barriers, then the JV is less likely to harm competition by raising prices. However, entry may not cause prices to fall below the current level as would elimination of JV restraints on independent competition by JV members using reasonably priced JV inputs.

10. Does JV membership or JV rules restrain the ability or incentives of the JV or its members to deal with competitors outside the JV, either as customers or as input suppliers? If so, then the JV could entail competitive harms from foreclosure, absent sufficient cognizable efficiency benefits, which suggests the need for further analysis. This concern would apply to vertical and complementary product JVs as well as horizontal JVs.

11. Would competitors of the JV be disadvantaged if they were to lose access to making sales to individual JV members (i.e., customer foreclosure) or obtaining the inputs or technologies provided by individual JV members (i.e., input foreclosure)? If so, then JV restraints on such relationships would raise foreclosure concerns. ${ }^{22}$ However, it generally is not sufficient to show harm to those competitors. It also would be necessary to show (or infer) harm to consumers. $^{23}$

\section{B. Potential Competitive Benefits}

A JV and its specific restraints can lead to cognizable efficiency benefits for consumers that can dominate the competitive harms. The following questions focus on these potential competitive benefits. Under a consumer welfare standard, efficiency benefits are cognizable only if they likely would be shared with consumers, rather than simply raising the profits of the JV or its members. Section $\mathrm{C}$ below addresses the weighing of the benefits and harms.

12. Are there likely significant cognizable efficiency benefits flowing from the formation and size of the JV? These benefits could include lower costs, new or higher quality products, more rapid innovation, and so on. If there are no such benefits, then a court might reasonably view a JV of actual or potential competitors as essentially a naked reduction in competition. Even if the JV is efficient, the agencies might be concerned that its membership is overly inclusive, suggesting the need to justify the membership size of the JV.

${ }^{21}$ In this situation, the JV might cause harm by charging high prices for the inputs it provides to members and non-members. This issue is discussed in Question 15.

22 For a detailed economic analysis of input and customers foreclosure emphasizing exclusive dealing and conditional pricing, see Steven C. Salop, The Raising Rivals' Cost Foreclosure Paradigm, Conditional Pricing Practices and the Flawed Incremental Price-Cost Test, ANTITRUST L.J. - (2016) (forthcoming), available at http://scholarship.law.georgetown.edu/facpub/1620/. See also Salop and Culley, supra note 14.

${ }^{23}$ Thomas G. Krattenmaker \& Steven C. Salop, Anticompetitive Exclusion: Raising Rivals' Costs to Achieve Power over Price, 96 YALE L.J. 209 (1986). 
13. As a general matter, are there likely significant cognizable efficiency benefits flowing from joint price setting or other joint conduct or restraints adopted by the JV? These benefits could include the need to set a price for a jointly produced product, elimination of free riding, and achievement of economies of scale. Even if certain cooperation inherent in the JV itself is procompetitive, some specific restraints or joint conduct included in the JV agreement may be anticompetitive. Any of those restraints (or that joint conduct) that are not reasonably necessary for competitive benefits could raise significant concerns about consumer harm, even if other aspects of the JV are beneficial. ${ }^{24}$

14. Specifically, if the members are restrained or disincentivized from competing with the JV (or among themselves), are there likely significant cognizable efficiency benefits from this particular restraint? These benefits could include cost reductions, elimination of opportunism or free riding that would raise costs or otherwise prevent the viability of the JV. If there are not cognizable competitive benefits sufficient to trump the harms from the loss in competition, then consumers would be harmed on balance.

15. If the individual members can compete independently only with the technology or inputs provided by the joint venture, and if the JV charges prices for those inputs or technology, are those prices set at or close to the minimum level that is necessary for the viability of the JV; or, is the JV being used as a profit center? A JV charging supracompetitive prices for these inputs can serve as a monopoly profit center for its members by raising the costs of members and thereby effectively restricting members' incentive and ability to charge lower, more competitive prices. In this way, the JV can be used to set monopoly prices to the customers of its members. ${ }^{25}$

16. If the JV rules restrain in any way the ability or incentive of the JV or its members to deal with outside competitors, what are the cognizable efficiency benefits flowing from these restraints, and are these benefits sufficient to prevent harms to consumers and competition? If there are competitive concerns from these restraints involving foreclosure, then such restraints would need to be justified, for example, by free rider or opportunism concerns.

17. If any of the JV restraints raise potential competitive concerns, are there practical alternatives to any of its restraints, such that there could be greater competition among the

24 For example, see NCAA, supra note 3. The NCAA had an efficient role in regulating college sports, restraints that were not at issue in the case. The case focused only on restraints on the independent negotiation of broadcast rights by the colleges.

${ }^{25}$ For example, consider a JV of competitors to create a joint sales agency, as in American Needle. See also Herbert J. Hovenkamp, American Needle: The Sherman Act, Conspiracy, and Exclusion, COMP. POL'Y INT'L ANTITRUST JOURNAL 1 (June 2010). If a court concludes that the JV has significant efficiency benefits, however, the extent to which a court would choose to evaluate the reasonableness of input prices charged to the JV members is not entirely clear. The same issue also may apply to the sale of JV inputs to non-members. 
members or by non-members, while still achieving the same or very similar cognizable efficiency benefits? If this is the case, then those more stringent restraints might not be considered reasonably necessary for consumer welfare, relative to these less restrictive alternatives. $^{26}$

\section{Likely Competitive Effects: Comparing Benefits and Harms}

If economic analysis finds that there are both likely competitive harms and likely competitive benefits, then the net competitive effect on consumers and the competition from those conflicting forces must be determined. In economic terms, this involves the impact on market output and quality-adjusted prices. These next questions are used to evaluate the net competitive effects. These competitive effects are evaluated with respect to both the overall JV and each of the specific restraints adopted by the JV. That is, in carrying out this analysis, it is important to carefully specify two relevant competitive benchmarks, (i) the but-for world absent specific restraint(s); (ii) the but-for world absent the JV.

18. Taking into account the likely harms and cognizable benefits of the overall JV, are consumers likely benefited or harmed on balance? Taking these effects into account, will the JV likely increase or decrease output? Will quality-adjusted prices likely rise or fall? If the $\mathrm{JV}$ and its restraints are beneficial on balance, then total market output should rise. While nominal prices might rise as a result of quality increases, a reduction in quality-adjusted prices would indicate that consumers are benefited on balance.

19. Taking into account the likely harms and cognizable benefits of each of the specific JV restraints, are consumers likely benefited or harmed on balance? How would the answer change if less restrictive alternative restraints were adopted instead? These involve the same output and quality-adjusted price impacts, but applied to specific restraints.

20. Are there any "natural experiments" that can be used to evaluate the impact of JV formation or JV restraints or subsequent conduct? Natural experiments can provide useful tests. For example, in a case like Cal Dental, natural experiment evidence might involve a comparison of prices and output before and after the restraints was instituted. Or it might compare prices and output in states with and without these restraints.

${ }^{26}$ For example, in today's digitally connected world, the ASCAP and BMI blanket licenses may no longer be necessary because the rights holders can unilaterally post prices, while the associations limit their roles to payment collection and monitoring. For example, see Stanley M Besen, Sheila N Kirby, Steven C Salop, An Economic Analysis of Copyright Collectives, 78 VIRGINIA L.R. 383, 407 (1992). A similar analysis might be made with respect to Visa and MasterCard card issuers unilaterally setting interchange fees in bilateral negotiations with merchants unconstrained by rules requiring merchants to accept the cards of all issuers. First Amended Complaint at X, Target Corp. v. Visa Inc., No. 1:13-cv-05745-JG-JO (E.D.N.Y. July 9, 2014), 2014 WL 4059235. 
